\title{
Väestön uusiutumiskyky ja aviollinen hedelmällisyys eri läänien kaupungeissa ja kauppaloissa sekä teollistumisasteeltaan erilaisissa maalaiskunnissa Suomessa vuosina 1950-51
}

\author{
Armas Nieminen.
}

\section{Tutkimustehtävä ja metodi.}

Muutama vuosi sitten selviteltiin Väestöpoliittisessa tutkimuslaitoksessa Suomen väestön ns. uusiutumislukujen sekä aviollisen hedelmällisyyden alueellisia eroavuuksia. Koska tällaiseen tutkimukseen tarvittavat tiedot väestön jakautumisesta iän, sukupuolen ja siviilisäädyn mukaan on saatavissa vain kymmenvuo-

- tisin väliajoin, 0:lla päättyviltä vuosilta, ja koska mainitussa selvityksessä jätettiin sota-aika tarkastelun ulkopuolelle, kohdistui se vuosiin 1938-39. Tuo tutkimus on julkaistu vuonna 1951 „ Väestöliiton vuosikirja III:ssa». ${ }^{1}$

Nyt esillä olevassa tutkimuksessa on pyritty selvittämään, millainen väestön uusiutumiskyky ja aviollinen hedelmällisyys maamme eri alueilla oli silloin, kun seuraavan kerran vuodenvaihteen 1940/41 jälkeen saatiin tietoja Suomen väestön rakenteesta. Koska tietolähteenä tällöin oli vuoden 1950 päättyessä toimitettu, ensimmäisen kerran koko maahamme kohdistunút todellinen väestönlaskenta, tarjoutui mahdollisuuksia monessa suhteessa täydellisempään ja asianmukaisempaan tutkimukseen, kuin mitä oli tuo aikaisempi. Näin ollen tämä tutkimus poikkeaa yleiseltä suunnittelultaan, laajuudeltaan ja metodiltaan joissakin suhteissa aikaisemmasta, vaikka tutkimustehtävä onkin sama. 
Syntyvyyden, kuolevuuden, väestönkasvun, uusiutumiskyvyn ja aviollisen hedelmällisyyden erilaisten mittausmenetelmien, niissä käytettyjen käsitteiden määrittelyn sekä uusiutumislukujen laskemisen suhteen viitataan tässä vain aikaisempaan tutkimukseen. Kuitenkin mainittakoon uudelleen seuraavat tutkimuksemme peruskäsitteet:

Yleisellä aviollisella hedelmällisyydellä tarkoitetaan vuoden kuluessa syntyneiden aviolasten määrää 1000 :a 15 -49 vuotiasta aviovaimoa kohden.

Aviollisilla erikoishedelmällisyysluvuilla taas tarkoitetaan kuhunkin viisivuotisikäryhmään kuuluvien aviovaimojen vuoden kuluessa elävänä synnyttämien lasten määrää 1000:a ko. viisivuotisikäluokkaan kuuluvaa aviovaimoa kohden.

Nettouusiutumisluku ilmoittaa, montako tyttölasta vastasyntynyt tyttölapsi keskimäärin elinaikanaan tulisi synnyttämään tiettyjen erikoishedelmällisyyslukujen ja eri ikäluokkien kuolemanvaaralukujen vallitessa. Tuo luku ilmaisee siis väestön »uusiutumiskyvyn» »pitkällä tähtäimellä», jos muuttoliikettä ei lainkaan oteta huomioon. Jos nettouusiutumisluku painuu jatkuvasti 1:n alapuolelle, ei väestö enää ole uusiutumiskykyinen.

Edellä mainitut tilastolliset käsitteet on otettu käytäntöön, jotta päästäisiin väestönkasvuilmiöitä selviteltäessä käsiksi olennaisempiin tekijöihin, kuin mihin käsitteet syntyneisyys, kuolleisuus ja luonnollinen väestönlisäys suovat mahdollisuuden. Viimeksi mainittuihinhan vaikuttavat väestön kulloinenkin sukupuoli- ja ikäryhmitys sekä aviosuhteet. Kuitenkin voidaan sanoa, että myös käsitteitä nettouusiutumisluku ja aviollinen hedelmällisyys käytettäessä vielä jäädään puolitiehen, ja tutkimus voi, kuten tämän tutkielman lopussa mainitaan, edetä syvemmälle.

Tämä tutkimus perustuu kunkin tutkimusalueen osalta vuoden 1950 väestönlaskennasta saatuihin väestön rakennetta koskeviin tietoihin sekä vuosien 1950-51 syntyneisyystilastoon. Myös syntyneiden jakaantuminen äidin iän mukaan on nyt otettu huomioon erikseen kunkin tutkimusalueen osalta eikä vain kunkin läänin kaupunkien ja maaseudun kohdalla, kuten aikaisemmassa 
tutkimuksessa meneteltiin. ${ }^{2}$ Nettouusiutumislukua laskettaessa tarvittavat tiedot väestön eloonjäämistodennäköisyydestä — jotka niin ikään koskevat vuosia $1950-51$ - sen sijaan on saatu koko maata koskevista naispuolisen väestön kuolleisuustauluista. ${ }^{3}$ Näin ollen eivät nettouusiutumislukuun tässä tutkimuksessa ole lainkaan päässeet vaikuttamaan kuolevuuden eroavuudet maan eri osissa.

Tässä tutkimuksessa on tarkoitus ensisijaisesti selvitellä väestön uusiutumiskyvyn ja aviollisen hedelmällisyyden riippuvuutta toisaalta alueellisesta sijainnista, toisaalta teollistumisasteesta. Myös suoritetaan - sikäli kuin se on mahdollista - vertail u a aikaisemman tutkimuksen tuloksiin.

Alueellisen sijainnin suhteen tyydytään tutkimuksessa vain läänijaon puitteisiin, minkä ohessa suurempia kaupunkeja ja kauppaloita tarkastellaan kutakin erikseen.

Aikaisemmassa tutkimuksessa otettiin teollistumisen vaikutus huomioon siten, että käsiteltiin erikseen kutakin kaupunkia, eri läänien kaupunkeja yhtenä ryhmänä, eri läänien maaseutua (kauppaloita ja maalaiskuntia) niinikään yhtenä ryhmänä sekä eräitä »puhtaita maatalouskuntia» eri lääneissä. Koska silloin ei ollut käytettävissä tietoja väestön ammattiryhmityksestä eri kunnissa, tuli noiden maatalouskuntien joukkoon joitakin varsin pitkälle teollistuneitakin kuntia (Viiala, Joutseno, Simpele), joten tältä osaltaan tuota tutkimusta ei voi pitää edustavana.

Nyt käsillä olevassa tutkielmassa on väestönlaskennan ansiosta voitu paljon paremmin kuin aikaisemmassa valaista nimenomaan teollistumisen vaikutusta tutkittaviin ilmiöihin. Nythän on käytettävissä tiedot väestön jakaantumisesta elinkeinohaaroittain kussakin kunnassa. ${ }^{4}$ Näin on voitu valita tyypillisiä maalaiskuntien ryhmiä, jotka edustavat enemmän tai vähemmän teollistuneita alueita.

Erikseen on tarkasteltu ensinnäkin kaikkia kaupunkeja, ${ }^{5}$ joissa väestönlaskennan mukaan vuoden 1950 päättyessä oli enemmän kuin 15000 asukasta, samoin kuin kauppaloitakin, joiden väkiluku ylitti tuon määrän ja joissa vuosina $1950-51$ oli itsenäinen väestökirjanpito, niin että niistä on tarvittavat tiedot saatavissa. 
Toisen tutkimusalueiden ryhmän muodostavat pienemmät kaupungit sekä kauppalat, joilla oli itsenäinen väestökirjanpito. Nämä käsitellään kunkin läänin puitteissa omana kokonaisryhmänään.

Maalaiskuntien osalta valittiin tutkimuksen kohteeksi kolme kuntatyyppiä niiden teollistumisasteen muk a a n. Tämän katsottiin olevan sitä korkeamman, mitä pienempi oli »a gra a ris u u den a s te» eli luku, joka ilmoittaa, suuriko osa kunnan väestöstä vuoden 1950 päättyessä sai elatuksensa maa- ja metsätaloudesta. Eniten teollistuneeseen kuntatyyppiin (kuntatyyppi I) valittiin kustakin läänistä kuntia, joissa »agraarisuuden aste» oli n. $45 \%$, keskityyppiin (II) kuntia, joissa se oli n. $60 \%$, sekä vähiten teollistuneeseen kuntatyyppiin (III) kuntia, joissa tuo luku oli n. $75 \%$. Näiden prosenttilukujen arvostelemiseksi mainittakoon, että vuoden 1950 päättyessä oli maa- ja metsätalouden piiriin luettavan väestön osuus koko väestöstä maan kaikissa maalaiskunnissa juuri valitsemamme toisen kuntatyypin mukainen: $60.0 \%$. Eri läänien maalaiskunnissa vastaava luku oli seuraava: Uudenmaan läänissä $42.0 \%$, Kymen 51.0, Hämeen läänissä 52.7, Ahvenanmaalla 54.2, Turun ja Porin läänissä 55.2, Vaasan 63,3, Lapin 67.2, Kuopion 68.2, Oulun 68.8 sekä Mikkelin läänissä $70.2 \%$. Vielä mainittakoon, että maalaiskuntia, joissa maa- ja metsätalousväestön osuus koko väestöstä vuoden 1950 päättyessä oli pienempi kuin $40 \%$, oli koko maassa 44 maalaiskuntien koko määrän noustessa 484:än, sekä maalaiskuntia, joissa puheena olevaa väestöä oli ainakin $80 \%, 28$.

I kuntatyyppiin kuuluvat tutkimusalueet muodostettiin siten, että kunkin läänin puitteissa tarkasteltiin yhtenä kokonaisuutena niitä maalaiskuntia, joissa »agraarisuuden aste» oli lähinnä $45 \%$ :a ja joiden yhteinen asukasluku kohosi - mikäli mahdollista - n. 15 000:een. Samaan tapaan muodostettiin tyyppiin II ja III kuuluvat tutkimusalueet. Täten saadut tutkimusalueet, niihin kuuluvat kunnat, niiden väkiluku sekä maalaiskuntien osalta niiden »agraarisuuden aste» käyvät ilmi liitetaulukosta 1. Tutkimusalueet jakaantuivat siis eri läänien osalle seuraavasti: 


\begin{tabular}{|c|c|c|c|c|c|c|c|}
\hline Täänt & $\begin{array}{l}\text { Yli } \\
\text { ast } \\
\text { kat }\end{array}$ & & $\begin{array}{l}\text { Pienem- } \\
\text { pien }\end{array}$ & & $\begin{array}{l}\text { isku } \\
\text { ntaty }\end{array}$ & & \\
\hline & kaup & & $\begin{array}{l}\text { kaupp. } \\
\text { ryhmä }\end{array}$ & I & II & III & \\
\hline Uudenmaan $\quad \ldots$ & 1 & - & 1 & 1 & 1 & 一 & 4 \\
\hline Turun ja Porin .. & 3 & - & 1 & 1 & 1 & 1 & 7 \\
\hline Ahvenanmaa $\quad \ldots$ & - & - & 1 & 一 & 1 & 一 & 2 \\
\hline Hämeen...... & 3 & 2 & 1 & 1 & T & 1 & 9 \\
\hline Kymen & 2 & 1 & $1-$ & 1 & 1 & 1 & 7 \\
\hline Mikkelin & 1 & - & 1 & - & 1 & $\Gamma$ & 4 \\
\hline Kuopion ....... & 1 & 1 & 1 & 1 & 1 & 1 & 6 \\
\hline Vaasan $\quad . . . . .$. & 2 & - & 1 & 1 & $\mathrm{r}$ & 1 & 6 \\
\hline Oulun $\ldots . . . .$. & 1 & - & 1 & 1 & 1. & 1 & 5 \\
\hline Lapin $\ldots .$. & 1 & - & 1 & 1 & 1 & 1 & 5 \\
\hline Kaikkiaan & 15 & 4 & 10 & 8 & 10 & 8 & 55 \\
\hline
\end{tabular}

I kuntatyyppiin kuuluvia maalaiskuntia ei ole ollut lainkaan Ahvenanmaalla eikä Mikkelin läänissä. Myös kuntatyyppi III Uudenmaan läänissä ja, Ahvenanmaalla olisi jäänyt väkiluvultaan niin pieneksi, ettei sitä ole näistä lääneistä katsottu tarkoituksenmukaiseksi ottaa mukaan. Silti ovat muutamat tutkimusalueet jääneet - kuten liitetaulukosta 1 näkyy - sopivien kuntien puutteessa väkiluvultaan 7000 :kin pienemmiksi. Tällaisia ovat Ahvenanmaan sekä Lapin läänien pienten kaupunkien ryhmät (Maarianhamina ja Tornio), kuntatyyppi I Kymen läänissä, kuntatyyppi II Ahvenanmaalla sekä kuntatyyppi III Hämeen läänissä.

\section{Tutkimuksen tulokset.}

\section{Väestön uusiutumiskyky.}

Tutkimuksen tulokset väestön uusiutumiskyvyn suhteen, mitattuna nettouusiutumisluvulla, näkyvät liitetaulukosta 2 ja sen perusteella tehdystä kuviosta 1 .

Jo ylimalkainen silmäys kuvioon osoittaa nettouusiutumisluvun riippuvuuden sekä teollistumisasteesta että paikkakunnan sijainnista. 
Teollistumisasteen suhteen kuvio osoittaa, että kussakin läänissä nettouusiutumisluku on kaupungeissa alhaisempi kuin missään maalaiskuntien ryhmässä ja että se kasvaa, mitä enemmän teollistuneeseen kuntaryhmään siirrytään. Ainoat poikkeukset tässä suhteessa ovat: Rauman kaupungissa, Hämeen läänin pienten kauppalain ryhmässä ja Varkauden kauppalassa nettouusiutumisluku oli yhtä suuri tai melkein yhtä suuri kuin vastaavan läänin eniten teollistuneessa maalaiskuntien ryhmàssä; Vaasan läänissä nettouusiutumisluku oli suurempi kuntaryhmässä I kuin II. Kaikkein alhaisimmat nettouusiutumisluvut todettiin maan suurimmissa kaupungeissa - Helsingissä, Turussa ja Tampereella - sekä Suomenlahden rannikolla sijaitsevissa pienemmissäkin kaupungeissa.

Vielä selvempänä kuin kuntien teollistumisasteen kuvio 1 paljastaa alueellisen sijainnin vaikutuksen nettouusiutumislukuun. Pieniä heilahduksia huomioon ottamatta tämä näet näyttää kaikissa kuntaryhmissä selvästi kasvavan siirryttäessä maan eteläosista pohjoista kohti seuraavassa järjestyksessä: Uudenmaan lääni, Turun ja Porin, Hämeen, Kymen, Vaasan, Mikkelin, Kuopion, Oulun sekä Lapin lääni. Näin asianlaita on sekä maalaiskuntien että kaupunkien kohdalla. Huomattavin poikkeus tässä suhteessa on, että Kuopion läänin kuntaryhmässä II nettouusiutumisluku on suhteellisen alhainen ja Vaasan läänin kuntaryhmässä I hyvin korkea.

Voimme sanoa, että alueellisen sijainnin vaikutus nettouusiutumislukuun on siinä mielessä suurempi kuin teollistumisasteen, että esim. Oulun läänin kaupungeissa - puhumattakaan pohjoisten läänien eniten teollistuneesta maalaiskuntien ryhmästä nettouusiutumisluku on suurempi kuin eteläisten läänien vähiten teollistuneessa maalaiskuntien ryhmässä.

Jos verrataan toisiinsa esim. Turun ja Porin sekä Lapin lääniä, joissa molemmissa kaikki kuntaryhmät ovat edustettuina, todetaan, että pohjoisimmassa läänissä oli kuntaryhmissä II ja III nettouusiutumisluku enemmän kuin $50 \%$ suurempi kuin tuossa eteläisessä läänissä sekä vähiten teollistuneessakin kuntaryhmässä 
lähes $50 \%$ suurempi. Samantapainen suhde näyttää pitävän paikkansa kaupunkeihinkin nähden.

Jos taasen kiinnitetään huomiota nettouusiutumisluvun absoIuuttiseen korkeuteen, todetaan, että tuo luku oli »kriitillisen rajan» - 1:n - yläpuolella kaikissa muissa tutkimusalueissa paitsi Helsingin, Turun ja Tampereen kaupungeissa sekä Kymen läänin pienten kaupunkien ja kauppalain (Hamina ja Kouvola) ryhmässä. Näin ollen väestö oli - edellyttäen vuosien 1950 - 51 hedelmällisyyssuhteet ja samojen vuosien koko maata koskevat kuolleisuussuhteet jatkuviksi - pitkälläkin tähtäimellä katsoen ja ottamatta lainkaan huomioon muuttoliikettä uusiutumiskykyistä. Mainituissa suurımmissa kaupungeissakin väestö oli miltei uusiutumiskykyistä, koskapa nettouusiutumisluku niissäkin oli vain vähän 1 :n alapuolella. Lapin, Oulun ja Kuopion läänien vähiten teollistuneessa maalaiskuntien ryhmässä väestö edellä mainituilla edellytyksillä enemmän kuin kaksinkertaistuisi sukupolven aikana.

Jos nettouusiutumisluvun absoluuttisen suuruuden suhteen vertaamme tämän tutkimuksen tuloksia aikaisempaan, joka perustui vuosien 1938 - 39 syntyneisyyteen ja vuosien 1936-40 kuolleisuuteen, toteamme suuren eron, joka hyvin kuvastaa sitä erilaisuutta, mikä vallitsee viime sotia edeltäneen ja niitä seuranneen ajan »väestötilanteen» välillä. Kun väestö nyt oli uusiutumiskykyistä kaikissa kaupungeissakin - muutamia poikkeuksia lukuunottamatta - oli se aikaisemmin sitä vain Kemin kaupungissa. Ja tuona aikaisempana ajankohtana nettouusiutumisluku oli 1:n alapuolella Ahvenanmaan sekä Uudenmaan ja Hämeen läänien maaseudullakin. Eikä väestö silloin pohjoisissakaan lääneissä osoittanut niin suurta uusiutumiskykyä, että se olisi yhden sukupolven aikana kaksinkertaistunut. Kun Helsinginkin väestö myöhempänä ajankohtana oli miltei uusiutumiskykyistä, olisi se aikaisemman tutkimuksen mukaan supistunut sukupolven kuluessa ajan mittaan puolella, ellei muutoliikettä oteta huomioon. Eri kuntaryhmissä syntyneisyys oli tarkastelemanamme myöhempänä ajankohtana niin paljon korkeampi ja kuolleisuus koko 
maassa siinä määrin alhaisempi, että vallitsevat hedelmällisyyssuhteet näyttivät koko maata ajatellen olevan aivan tarpeeksi korkeat turvaamaan väestön jatkuvan huomattavankin kasvun. Koko maan nettouusiutumisluku olikin vuosina $1950-51 \quad 1.40$.

Asetettaessa muissa suhteissa tämän tutkimuksen tulokset aikaisempien rinnalle huomataan, että kummastakin voidaan tehdä sanhat yleiset - edellä esitetyt - johtopäätökset toisaalta alueellisen sijainnin vaikutuksesta nettouusiutumislukuun ja toisaalta siitä eroavuudesta, joka tässä suhteessa vallitsee kaupunkien ja maaseudun kesken. Kuitenkin alueellisen sijainnin vaikutus nettouusiutumislukuun kaupunkien kohdalla on tässä tutkimuksessa selvempi kuin aikaisemmassa. Kun viimeksi mainitussa eri läänien kaupunkien nettouusiutumisluvut eivät - suurempia kaupunkeja lukuun ottamatta - yleensä eronneet toisistaan kovinkaan paljon, on tämän tutkimuksen mukaan nettouusiutumisluku myös kaupungeissa pohjoisissa lääneissä huomattavasti korkeampi kuin eteläisissä. Yksityisten kaupunkien nettouusiutumislukuja tarkasteltaessa on kuitenkin huomattava, että tässä tutkimuksessa noudatettu metodi on etenkin kaupunkien osalta tarkempi kuin aikaisemman, koska silloin käsiteltiin erikseen tilastollisten johtopäätösten kannalta väkiluvultaan hyvin pieniäkin kaupunkeja ja koska tässä tutkimuksessa on syntyneiden jakautuminen äidin iän mukaan otettu huomioon kunkin tutkimusalueen kohdalta erikseen, eikä perustana ole pidetty kunkin läänin kaikista kaupungeista tai maaseudulta laskettua ko. jakautumaa, kuten aikaisemmin meneteltiin.

Toisin kuin kaupungeissa ei tässä tutkimuksessa maaseudun osalta enää voi todeta aivan yhtä suuria eroja nettouusiutumisluvun suhteen maan eteläisimpien ja pohjoisimpien osien kesken kuin aikaisemmassa tutkimuksessa.

Vielä voidaan kiinnittää huomiota siihen, että 1940-luvulla maan suurimpienkin kaupunkien nettouusiutumisluku on noussut suhteellisesti enemmän kuin maaseudun, niin että tutkimuksissa esiintyvien kaikkein matalimpien ja korkeimpien lukujen väliset eroavuudet eivät enää ole läheskään yhtä suuria kuin aikaisemmin. 


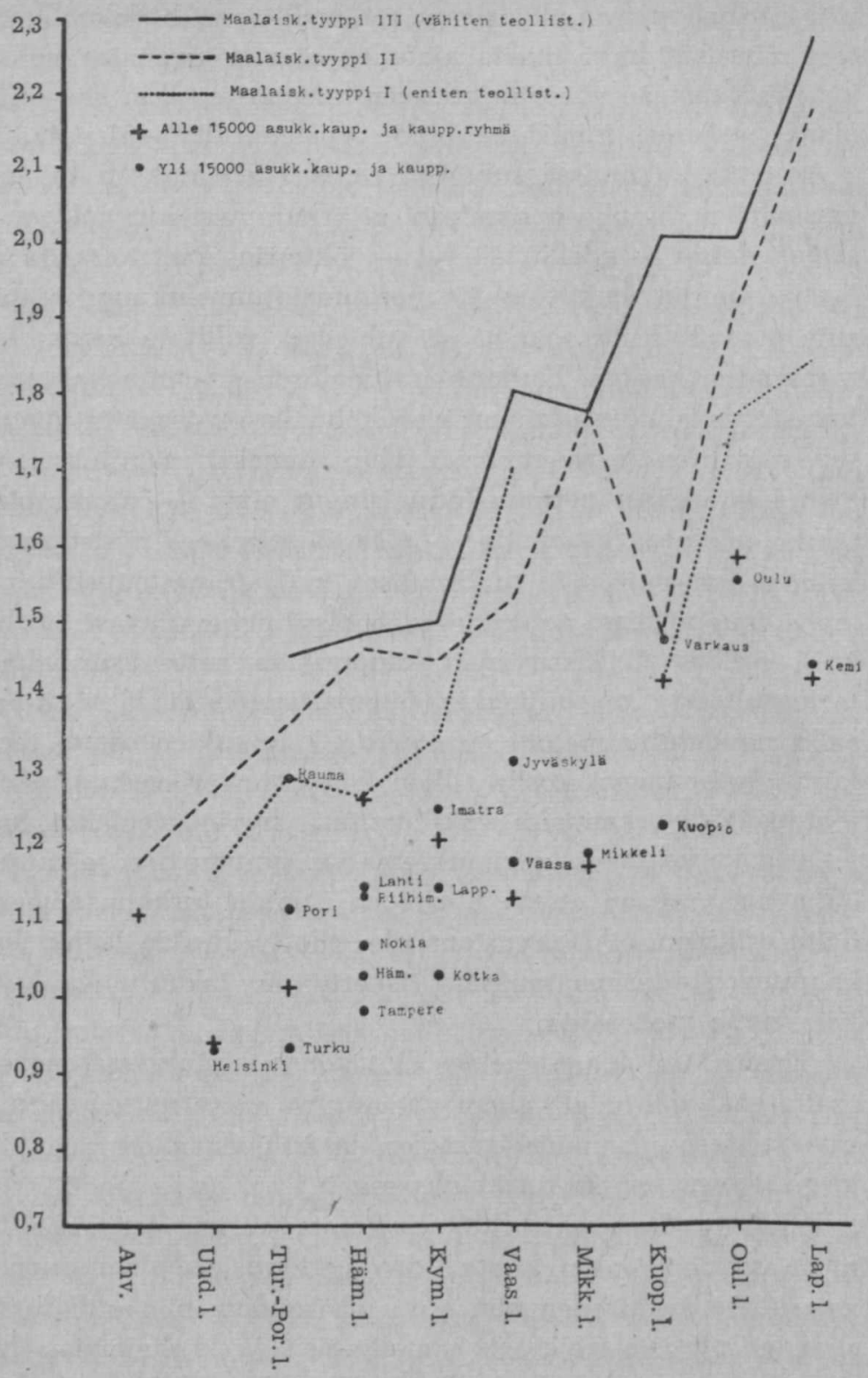

Kuvio 1. Nettouusiutumisluku vv. 1950-51. 


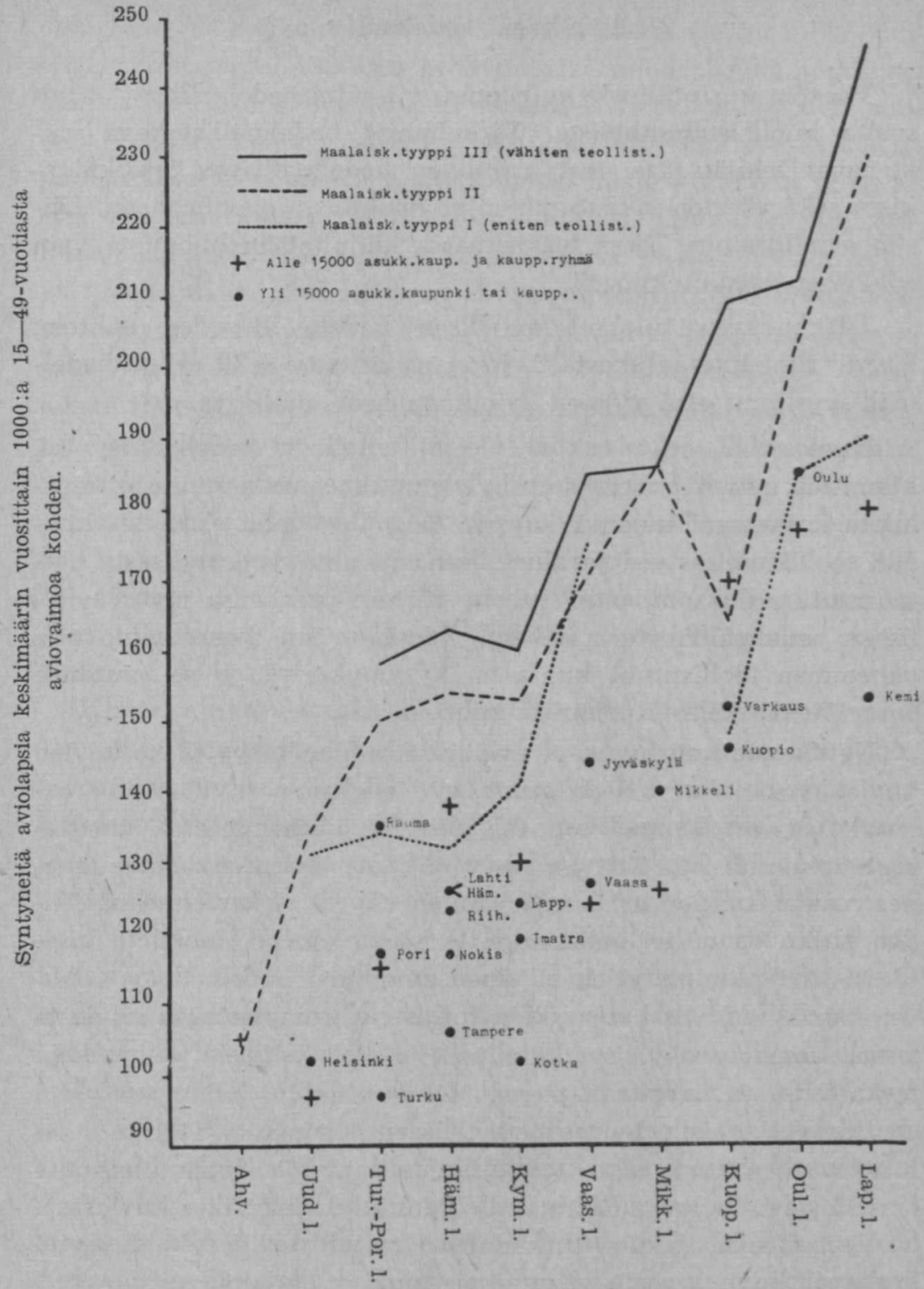

Kuvio 2. Aviollinen hedelmällisyys vv. 1950-51. 


\section{Aviollinen hedelmällisyys.}

Väestön uusiutumiskyky riippuu toisaalta hedelmällisyys-, toisaalta kuolleisuussuhteista. Tärkeimmät hedelmällisyyteen vaikuttavat tekijät taas ovat aviollinen hedelmällisyys eri ikäluokissa sekä väestön jakautuminen ei-avioliitossa oleviin ja eri ikäisiin avioliittoihin. Tässä tutkielmassa kiinnitetään huomiota vain edelliseen näistä tekijöistä.

Tutkimuksen tulokset aviollisen hedelmällisyyden suhteen käyvät ilmi liitetaulukosta 3 , jossa on esitetty sekä erikoishedelmällisyysluvut että yleinen aviollinen hedelmällisyys.

Kuviossa 2, joka esittää yleistä aviollista hedelmällisyyttä, kiinnittää heti huomiota suuri yhdenmukaisuus nettouusiutumislukua koskevan kuvion 1 kanssa. Se, mitä edellä esitettiin kunnan teollistumisasteen ja alueellisen sijainnin vaikutuksesta nettouusiutumislukuun, pitää suurin piirtein paikkansa myös aviolliseen hedelmällisyyteen nähden. Tämä on sitä korkeampi, mitä vähemmän teollistunut kunta on kysymyksessä, ja se suurenee siirryttäessä etelästä pohjoista kahti.

Nettouusiutumislukua ja aviollista hedelmällisyyttä koskevien kuvioiden nojalla voidaan sanoa, että edellisessä ilmenevät eroavuudet saavat luonnollisen selityksensä jälkimmäisessä tavattavista eroavuuksista. Erityisen selvänä tämä yhdenmukaisuus ilmenee maalaiskuntien eri kuntaryhmien käyriä tarkasteltaessa. Niiden kulku on miltei poikkeuksetta samanlainen. Huomiota kiinnittää kuitenkin erityisen alhainen aviollinen hedelmällisyys Ahvenanmaalla. Myös kaupunkien tutkistelu kummastakin kuviosta antaa samanlaisen yleisvaikutelman, mutta yksityisiä kaupunkeja tarkasteltaessa havaitaan pieniä eroavuuksiakin, joihin selityksiä etsittäessä voitaisiin turvautua erilaiseen ikäryhmitykseen ja avioliittoisuuteen (vrt. esim. toisaalta Helsingin ja Turun, toisaalta taas Hämeenlinnan ja Riihimäen sijaintia kummassakin kuviossa).

Verrattaessa tämän tutkimuksen aviollista hedelmällisyyttä koskevaa kuviota vastaavaan aikaisemmassa tutkimuksessa esitettyyn todetaan, että ne antavat samantapaisen kuvan aviollisen he- 
delmällisyyden eroavuuksien ratkaisevuudesta tiettynä ajankohtana nettouusiutumisluvun eroavuuksiin nähden sekä myös eri läänien välisistä eroavuuksista aviollisen hedelmällisyyden suhteen. Vaikka esitetyt käyrät onkin piirretty osittain erilaisilla perusteilla nyt ja aikaisemmin, voidaan niistä kuitenkin päätellä, että aviollinen hedelmällisyys ei ole noussut läheskään niin suuressa määrässä kuin nettouusiutumisluku. Maalaiskuntien aviollista hedelmällisyyttä esittävät käyrät osoittavat, että nettouusiutumisluvun nousussa on paljon vaikuttavampi tekijä kuin aviollisen hedelmällisyyden kohoaminen ollut kuolleisuuden aleneminen. Sen sijaan useimmissa niistä kaupungeista, joista aviollinen hedelmällisyys on erikseen laskettu kummallakin kerralla, on se kuluneen 10-vuotiskauden aikana huomattavasti noussut.

Aviolliset erikoishedelmällisyysluvut maalaiskuntain eri kuntatyypeissä on esitetty liitetaulukossa 3 sekä kuvioissa $3 \mathrm{~A}$ ja $3 \mathrm{~B}$. 15-19-vuotiaiden sekä 45-49-vuotiaiden ikäluokat on kuitenkin jätetty kuviosta pois samoista syistä kuin edellisessäkin tutkimuksessa. ${ }^{6}$

Kuviot osoittavat sekä teollistumisasteen nousun että siirtymisen pohjoiseen päin vaikuttavan hedelmällisyyttä lisäävästi paljon voimakkaammin 40-44-vuotiaiden kuin 20-24-vuotiaiden keskuudessa. Erikoishedelmällisyysluku on Lapin läänissä Ahvenanmaan vastaavaan lukuun verrattuna ikäryhmässä 40 - 44-vuotiaat n. 4.5-kertainen, kun sen sijaan 20-24-vuotiaiden suhteen ei voi havaita selviä eroja maan eri osien kesken. Nuoremmissa ikäluokissa eri kuntatýyppejä esittävät käyrät ovat etelä-Suomessa sotkeutuneet toisiinsa, ja vasta 35-39-vuotiaiden kohdalla käyrät ovat melko selvästi sekä 40-44-vuotiaiden suhteen aivan selvästi erillään toisistaan. Näin siis nuorten aviovaimojen hedelmällisyydessä ei tavata niin selviä eroja kuin vanhempien toisaalta maan eri osissa ja toisaalta teollistumisasteeltaan erilaisissa kunnissa.

Sikäli kuin nyt esitettyjä aviollisia erikoishedelmällisyyslukuja koskevia käyriä voi verrata edellisessä tutkimuksessa esitettyihin, antavat ne eri läänien välisistä eroavuuksista suunnilleen samanlaisen kuvan. 


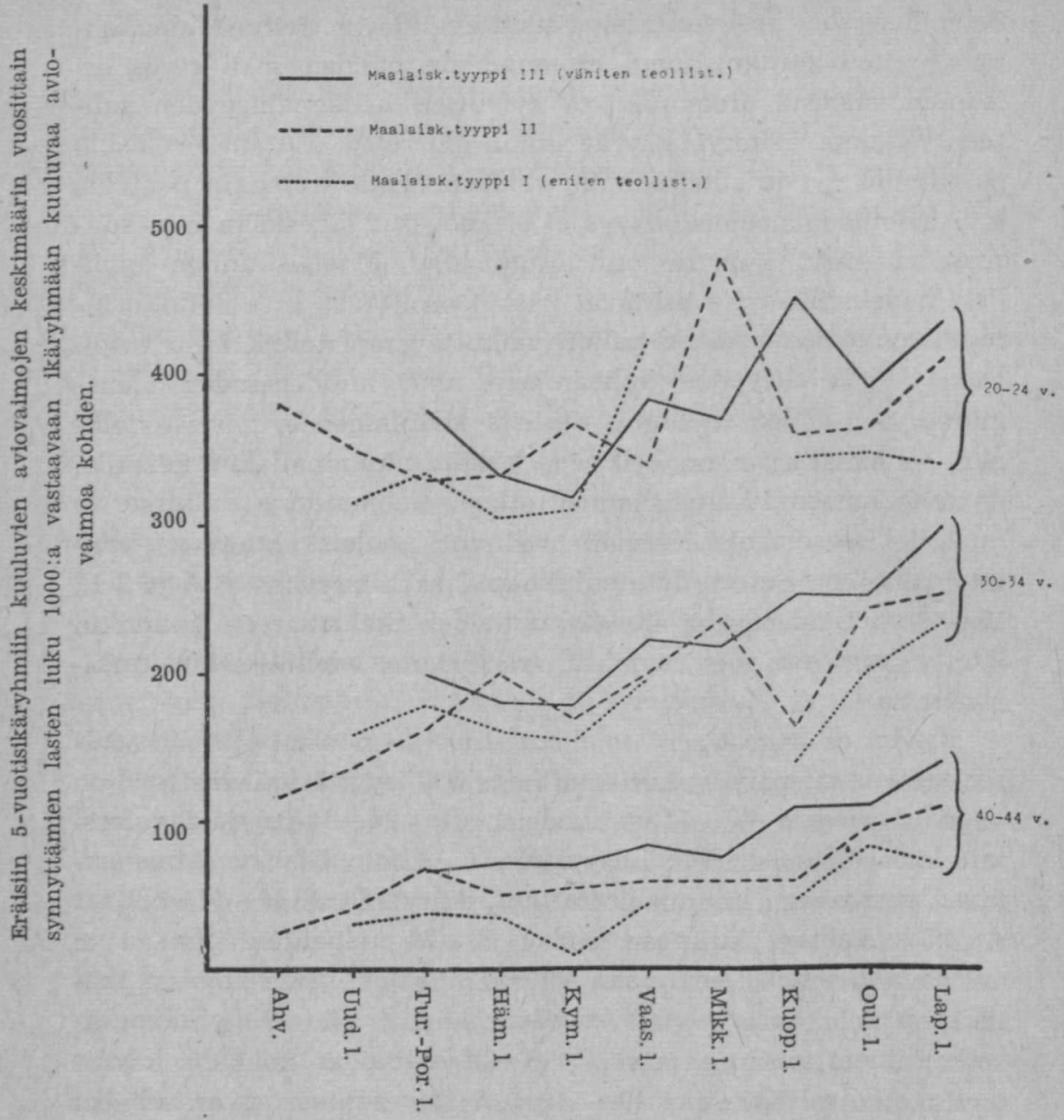

Kuvio 3 A. Ikäluokkien $20-24$ v., 30-34 v. ja 40-44 v. aviolliset erikoishedelmällisyysluvut eri maalaiskuntatyypeissä vv. 1950-51.

III. Loppukatsaus ja viittaus uusiin tutkimuksiin.

Edellä on pyritty selvittämään, millainen vaikutus toisaalta alueellisella sijainnilla, toisaalta teollistumisasteella on ollut väestön uusiutumiskykyyn, sikäli kuin nettouusiutumisluku tämän voi 




Kuvio 3 B. Ikäluokkien 25-29 v. ja 35-39 v. aviolliset erikoishedelmällisyysluvut eri maalaiskuntatyypeissä vv. 1950-51.

ilmaista, samoin kuin aviolliseen hedelmällisyyteenkin vuosina 1950-51. On myös verrattu tämän tutkimuksen tuloksia aikaisempaan vuosien 1938 - 39 syntyneisyyteen ja vuosien $1936-40$ kuolleisuuteen perustuvaan vastaavanlaiseen, mutta metodiltaan osittain erilaiseen tutkimukseen. Uusiutumiskykyä selviteltäessä ei kuitenkaan ole voitu ottaa huomioon kuolevuuden eroja maan 
eri osissa, joten tutkimus valaisee tässäkin suhteessa etupäässä vain hedelmällisyyden merkitystä.

Tässä tutkimuksessa nettouusiutumisluvut ovat kauttaaltaan huomattavasti suurempia kuin aikaisemmassa. Vuosien 1950-51 hedelmällisyys oli siksi korkea ja kuolleisuus siksi alhainen, että ne edellyttivät melkoista väestönkasvua. Vain kolmen suurimman kaupungin sekä Uudenmaan läänin pienempien kaupunkien ryhmän nettouusiutumisluku oli 1:tä alhaisempi. Näidenkin kohdalla luku oli kyllä hyvin lähellä tuota arvoa. Juuri niissä nettouusiutumisluvun kasvu onkin ollut erityisen suuri.

Nettouusiutumisluvun kohoaminen johtuu ratkaisevasti kuolleisuuden huomattavasta alenemisesta 1940-luvulla. Sen sijaan aviollisen hedelmällisyyden noususta voidaan — sikäli kuin se tästä tutkimuksesta on pääteltävissä - puhua vain kaupunkien kohdalla.

Alueellisen sijainnin ja teollistumisasteen vaikutus on ollut suunnilleen samanlainen sekä nettouusiutumislukuun että aviolliseen hedelmällisyyteen. Näin ollen voidaan aikaisemman tutkimuksen tapaan sanoa, että ratkaiseva tekijä väestön uusiutumiskyvyn alueellisissa eroissa on ollut juuri aviollinen hedelmällisyys. Kuolevuuden merkitys tässä suhteessa ei tässä tutkimuksessa kuitenkaan ole tullut valaistuksi. Kaupunkien kohdalla on myös väestön ikäryhmityksellä ja aviosuhteilla huomattava merkitys.

Teollistumisaste on vaikuttanut sekä nettouusiutumislukuun että aviolliseen hedelmällisyyteen siten, että nämä ovat suuremmat maaseudulla kuin kaupungeissa, ja sitä suuremmat, mitä vähemmän teollistunut kuntatyyppi on kysymyksessä.

Vielä huomattavampi kuin teollistumisen on alueellisen sijainnin vaikutus, vaikka tässä onkin - aikaisempaan tutkimukseen verrattuna - maaseudun suhteen havaittavissa jonkin verran heikkenemistä. Kaikissa kuntaryhmissä luvut nousevat siirryttäessä etelästä pohjoiseen päin. Lasten lukumäärä perheissä on pohjoisessa noin puolta suurempi kuin etelässä silloinkin, kun on kysymyksessä samalla teollistumisen asteella oleva paikkakunta. 
Sekä teollistumisen asteen että alueellisen sijainnin vaikutus aviolliseen hedelmällisyyteen on suhteellisesti sitä suurempi, mitä vanhemmat ikäluokat ovat kysymyksessä. Nuorempien keskuudessa ei sen sijaan ole niin suuria eroavuuksia havaittavissa. Kymmenen vuoden aika on kuitenkin siksi lyhyt, että aikaisempi ja myöhempi tutkimus antavat sentään suunnilleen samanlaisen kuvan niistä eroavuuksista, joita on havaittavissa nettouusiutumisluvun ja aviollisen hedelmällisyyden suhteen eri alueilla.

Tämän tutkimuksen tarkoituksena on ollut vain esittää laskelmia teollistumisen asteen ja alueellisen sijainnin vaikutuksesta nettouusiutumislukuun ja aviolliseen hedelmällisyyteen. Sen sijaan tässä on voitu vain viitata tutkimusten tulosten lähempään selittämiseen ja analyysiin. Tämä edellyttäisi kunkin tutkimusalueen piirissä havaitsemiemme seikkojen asettamista yhteyteen k aikkien niiden osatekijäin kanssa, jotka vaikuttavat nettouusiutumislukuun ja aviolliseen hedelmällisyyteen (väestön ikä-, sukupuoli- ja siviilisäätyryhmitys, avioliittojen jakautuminen niiden kestoajan mukaan, aviollinen hedelmällisyys eri avioliittoryhmissä, avioton hedelmällisyys jne.).

Yrittäessämme syventyä näihin kysymyksiin joudumme toteamaan itse peruskäsitteittemme - uusiutumisluvun ja aviollisen hedelmällisyyden - riittämättömyyden väestönkasvua tutkittaessa. Siten tutkimuksemme päätyy ajatuksiin, joita nykyään varsin voimakkaasti korostetaan väestötieteellisessä kirjallisuudessa. $^{7}$

Voidaan nimittäin sanoa, että hedelmällisyys on kulttuurissa, jossa syntyvyyden säännöstely on yleistynyt, varsin herkkä vaihteluille, mikä seikka supistaa hedelmällisyyden ja uusiutumislukujen käyttökelpoisuutta vastaisen kehityksen ennakoimisessa. Olemme tässäkin tutkimuksessa nähneet, miten kokonaan toisenlaiset näköalat tulevaisuuden suhteen aukenevat aikaisemmassa ja tässä tutkimuksessa. 
Toiseksi nuo käsitteet ovat melko kaavamaisia. Niitä käytettäessä annetaan ratkaiseva merkitys syntyneiden jakaantumiselle äidin iän mukaan. Tulevaa kehitystä ennakoitaessa voi kuitenkin olla tarpeen kiinnittää yhtä suurta huomiota esim. sellaisiin seikkoihin, kuin miten syntyneet jakautuvat isän iän tai avioliiton kestoajan tai järjestysluvun mukaan, suuriko osa väestöstä ei elä aviöliitossa, miten yleisesti avioliitot purkautuvat jne. Sen tähden ollaankin yhä enemmän suuntautumassa tutkimaan eri vuosina syntyneiden tai eri vuosina avioituneiden väestöluokkien - ns. kohorttien - kehitystä: Täten voidaan paremmin ottaa huomioon asenteiden ja tapojen muutokset, joita kehitys tuo mukanaan ja jotka ilmenevät myös perheiden lapsiluvussa. Tämänlaatuisten tutkimusten tarpeellisuus tunnetaan, mutta käytännössä tällainen tutkimustyö on vielä ollut varsin vähäistä Suomessa samoin kuin monissa muissakin maissa.

Nettouusiutumisluku- ja hedelmällisyyskäsitteitä ei näin ollen ole syytä pitää niin »arvovaltaisina», kuin mitä asianlaita oli vielä 1940-luvulla. Niitäkin käyttäen voidaan suorittaa vain väestönkehityksen »karkeita» selvittelyjä. Syvemmälle menevän tutkimuksen olisi turvauduttava uudempiin menetelmiin. Mutta muistaen puheena olevien käsitteiden rajoituksen voidaan niidenkin antamista tiedoista sentään lukea kehitykselle olennaisia piirteitä. Tässä tutkimuksessa on pyritty jatkamaan ja teollistumisen vaikutuksen suhteen syventämään aikaisempaa, vuosiin $1938-39$ kohdistunutta tutkimusta selvittämällä, millainen tilanne on ollut vuosina $1950-51$, ja siten valaisemaan eräitä Suomen väestön nykypäivien kehityksen olennaisia puolia. 


\section{Lähdeviitteitä ja huomautuksia.}

1 Nieminen, Armas, Suomen väestön uusiutumiskyvyn ja aviollisen hedelmällisyyden alueellisista eroavuuksista vuosina 1938-1939, Väestönkehityksen ja avioliiton ongelmia (Väestöliiton vuosikirja III), Helsinki 1951, ss $37-58$.

2 Väestön jakaantumista län, sukupuolen ja siviilisäädyn mukaan koskevat tiedot kunkin tutkimusalueen kunnista on poimittu väestönlaskenta-aineistosta tilestollisesta päätoimistosta. Tiedot syntyneistä on saatu niinikään siellä säilytetyistä seurakunnittaisista syntyneiden luetteloista sekä seuraavista lähteistä: Suomen tilastollinen vuosikirja (STV) 1952, T (= taulu) 44; 1953, T 48; Helsingin kaupungin tilastollinen vuosikirja 1952 ja 1953, T 44 C; Tampereen kaupungin tilastollinen vuosikirja 1952, T 38. Elävänä syntyneet, joiden äidin ikä oli alle 15 vuctta, on luettu ikäryhmään $15-19$ v., ne, joiden äidin ikä oli yli 49 v., 45-49vuotiaisiin. Ne taas, joiden äidin ikä oli tuntematon, on jaettu eri ikäryhmiin samassa suhteessa kuin ne elävänä syntyneet (vastaavasti: elävänä syntyneet aviolapset), joiden äidin ikä oli tunnettu. Tyttöjen osuutta kaikista elävänä syntyneistä osoittava suhdeluku $(0.48662)$ on kuitenkin laskettu koko maasta 5-vuotiskaudelta $1949-53$. STV 1954, T 49.

3 Tilastokatsauksia $10 / 1953$, s. 41. Tässä tutkimuksessa ei ole ctettu huomioon kaupunkien ja maaseudun kesken vallitsevaa kuolevuuden eroavuutta, koska tämä ei ilmene vuosien 1950-51 kuolleisuustauluista. Kaupunkien ja maaseudun väestön kuolemanvaaran eroavuus onkin nykyään vähäinen. Vrt. Suomen virallinen tilasto (SVT) VI A 108, ss. 15, 22-23.

4 Tiedot kuntien väestön elinkeinoryhmityksestä on saatu tilastcllisen päätoimiston väestönlaskentaosaston toimittamasta monisteesta 》Väestö elinkeinohaaran mukaan 31. 12. 1951, suhdeluvut». Nämä tiedot sisältyvät painatuksen aikana ilmestyneeseen julkaisuun SVT VI C 102:2, T 1. Tiedot kuntien väkiluvusta: STV 1954, T 16.

5 Hämeenlinnan kaupungin suhteen - jonka osalta tutkimustulokset ensin näyttivät muodostuvan poikkeuksellisiksi - on tutkimuksessa täytynyt turvautua erinäisiin arviointeihin sen vuoksi, että mainittuun kaupunkiin vuoden 1948 alussa liitettiin laajoja alueita Hämeenlinnan maalaiskunnasta, joka silloin kokonaan hajoitettiin, samoin kuin Vanajasta. Nämä liitosalueet sisältyivät siten kaupunkiin väestönlaskennassa. Ilmeisesti Vanajan kunnasta kaupunkiin liitetyllä alueella syntyneet ovat kuitenkin aina vuoden 1953 alkuun saakka, jollcin vasta alueliitosta vastaava muutos seurakunnallisessa suhteessa tapahtui, sisältyneet Vanajan kunnan syntyneisyystilastoon. Viralliset väestönmuutostiedot Hämeenlinnan kaupungin osalta ovat siis vuosilta $1950-51$ jääneet aivan lian pieniksi. Sen tähden tässä tutkimuksessa on Hämeenlinnassa tutkimusvuosina syntyneiden määrä kerrottu luvulla, joka saadaan, kun Vanaján kunnasta vuoden 1948 alussa henkikirjojen mukaan kaupunkiin siirretty väestö ( 3230 henkeä) jaetaan Hämeenlinnan kaupungin väkiluvulla vuoden 1950 päättyessä. SVT VI A 104, s. 7. Vrt. Tuura, Antti, Hämeenlinnan väestö, sen asunto-olot ja asunnontarve, julkaisematon tutkielma 1954, Väestöpoliittinen tutkimuslaitos, ss. $11-13$.

6 Nieminen, m.k., s. 52.

7 Ks. tästä kokoavana yleisesityksenä esim.: Stolnitz, George J.-Norman B. Ryder, Recent Discussion of the Net Reproduction Rate, Population Index 1949 (Princeton, N. J., U.S.A), ss. 114-T28. Tähän kirjoitukseen liittyy erittäin laaja bibliografia. 
I. Kaupungit ja ka palat.

Väkiluku

Väkiluku

31. 12.50

31.12 .50

Uudenmaan lääni

369380

Helsinki .........
Muut kaupungit

(Porvoc, Hanko, Tammisaari, Loviisa) .. 24311

Turun ja Porin lääni

Turku $\ldots \ldots \ldots \ldots \ldots \ldots \quad 101824$

Pori $\ldots \ldots \ldots \ldots \ldots \ldots \quad 43213$

Rauma $\quad$........... 15406

Muut kaup. ja kaupp.

(Uusikaupunki, Naantali, Salon kaupp.,

Loimaan kaupp.) .. 18922

Ahvenanmaa

Maarianhamina ..... 3273

Hämeen lääni

Tampere ............ 101143

Lahti $\quad . \ldots \ldots \ldots \ldots \ldots .44652$

Hämeenlinna ........ 22354

Riihimäen kaupp. .... 16718

Nokian kaupp. ...... 15508

Muut kauppalat

. (Valkeakoski, Forssa, Mänttä, Toijala) 32388

Kymen lääni

Kotka ............ 23949

Lappeenranta $\quad$....... 17189

Imatran kaupp. ..... 28087

Muut kaup. ja kaupp.

(Hamina, Kouvolan

kaupp.) $\quad \ldots \ldots \ldots \ldots \ldots \quad 17592$

Mikkelin lääni

Mikkeli $\quad$........... 15895

Muut kaupungit

(Savonlinna, Heinola) 20161 Kuopion lääni

Kuopio

33353

Muut kaupungit

(Joensuu, Iisalmi) .. 12650

Varkauden kaupp. .... 17640

Vaasan lääni

Vaasa ............ 34999

Jyväskylä $\quad \ldots \ldots \ldots \ldots \ldots$..... 30661

Muut kaup. ja kaupp.

(Kokkola, Pietarsaari,

Kristiinankaupunki,

Kaskinen, Uusikaarle-

pyy, Suolahden

kaupp.) (......... 36235

Oulun lääni

Oulu ............ $\quad 37910$

Muut kaupungit

(Kajaani, Raahe) .. 15532

Lapin lääni

Kemi $\quad \ldots \ldots \ldots \ldots \ldots .23529$

Tornio ........... 3282 
II. Ma a l is kun at.

(Kunnan nimen jälkeen mainittu numero ilmaisee, montako \% kunnan asukkaista 31. 12. 1950 väestönlaskennan mukaan sai elatuksensa maa- ja metsätaloudesta.)

Uudenmaan lääni

Väkiluku

31. 12.50

Kuntatyyppi I (Sipoo 44.2, Orimattila 46.3)

24202

II (Mäntsẩlä 58.8, Inkoo 60.1, Askola 60.3, Pornainen 61.4, Nummi 61.9) ......................... 26429

Turun ja Porin lääni

Kuntatyyppi I (Vestanfjärd 43.9, Korppoo 44.8, Paimio 46.2, Koke-



II (Kalanti 59.1, Pcmarkku 60.0, Viljakkala 60.2, Uudenkaupungin mlk. 60.4, Taivassalo 60.7) ........... 15644

III (Marttila ja Kuusjoki 73.4, Lemu 73.6, Kullaa 74.7,

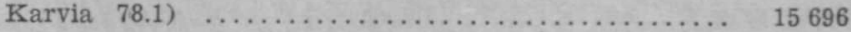

Ahvenanmaa

Kuntatyyppi II (Geta 58.6, Sund 59.5, Vârdö. 60.5, Hammarland 63.1) 4257 Hämeen lääni

Kuntatyyppi I (Hollola 43.4, Hausjärvi 46.5)

20515

II (Pälkäne 58.5, Luopioinen 59.4, Loppi 61.2) ........ 19269

Kymen lääni

III (Tottijärvi 71.8, Somerniemi 75.2, Koskenpää 77.0) .. 6453

Kuntatyyppi

I (Pyhtää 44.3)

5544

II (Parikkala 56.3, Elimäki 63.2) ................ $1761 \mathrm{I}$

Mikkelin lääni

III (Ruokolahti 74.4, Savitaipale 76.5) ............ 15962

Kuntatyyppi II (Punkaharju 54.5, Mikkelin mlk. 63.5) .......... 17669

III (Kangasniemi ja Kangaslampi 75.0, Hartcla 75.2) .. 20681

Kuopion lääni

Kuntatyyppi I (Suonenjoki 49.9)

10977

II (Kuopion mlk. 59.7, Sillinjärvi 59.9) $\ldots \ldots \ldots \ldots \ldots 16752$

Vaasan lääni

III (Nilsiä 74.4, Kilhtelysvaara 75.2, Valtimo 75.6) $\ldots .20082$

Kuntatyyppi I (Keuruu 44.8)

11027

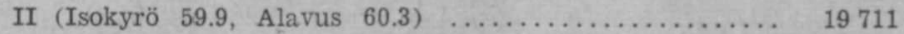

III (Pihtipudas 74.9, Maalahti ja Pylkönmäki 75.1) .... 14196

Oulun lääni

Kuntatyyppi I (Oulujoki 40.5, Muhos 43.2, Oulunsalo 48.7, Kempele 49.8)

17455

II (Paavola 59.7, Ii 60.2 , Kalajoki 60.4) $\ldots \ldots \ldots \ldots \ldots$

19069

III (Sotkamo 74.2, Sievi 75.8)

20928 


\section{Lapin lääni}

Kuntatyyppi I (Kemin mlk. 47.2, Inari 48.4)

9983

II (Kemijärvi 59.0, Muonic 60.0, Enontekiö 60.r) $\ldots \ldots .16252$

III (Kittilä 72.9, Karunki 75.0, Kolari 77.9) ......... 14433

Liitetaulukko 2. Nettouusiutumisluku vv. 1950-51.

Uudenmaan $l$.

Helsinki ............ 0.931

Muut kaup. $\ldots \ldots \ldots \ldots .0 .938$

I kuntatyyppi $\ldots \ldots \ldots \quad 1.163$

II $\quad$ II $\quad \ldots \ldots \ldots .1 .268$

Turun ja Porin $l$.

Turku $\ldots \ldots \ldots \ldots \ldots \ldots \quad 0.933$

Pori $\quad \ldots \ldots \ldots \ldots \ldots \ldots \ldots . \ldots \ldots$

Rauma $\quad$............ 1.291

Muut kaup. ja kaupp. . . 1.013

I kuntatyyppi $\ldots \ldots \ldots .1 .291$

II $\quad " \quad \ldots \ldots \ldots .1 .364$

III $\quad, \quad \ldots \ldots \ldots, 1.452$

Ahvenanmaa

Maarianhamina $\quad . . \ldots \ldots .1 .107$

II kuntatyyppi $\quad \ldots \ldots \ldots .1 .176$

Hämeen $l$.

Tampere ............ 0.980

Lahti $\ldots \ldots \ldots \ldots \ldots \ldots .1 .144$

Hämeenlinna .......... 1.027

Riihimäki $\ldots \ldots \ldots \ldots \ldots \quad 1.139$

Nokia $\ldots \ldots \ldots \ldots \ldots \ldots . . .66$

Muut kaupp. ......... 1.261

I kuntatyyppi $\ldots \ldots \ldots \quad 1.268$

II $\quad, \quad \ldots \ldots \ldots .1 .462$

III $\quad " \quad \ldots \ldots . \quad 1.484$

Kymen $l$.

Kotka .............. 1.028

Lappeenranta $\ldots \ldots \ldots \ldots \quad 1.144$

Imatra $\ldots \ldots \ldots \ldots \ldots \ldots \quad 1.249$

Muut kaup. ja kaupp. .... 1.206

I kuntatyyppi $\ldots \ldots \ldots, 1.342$

II $\quad, \quad \ldots \ldots \ldots .1 .448$

III $\quad, \quad \ldots \ldots \ldots .1 .499$
Mikkelin $l$.

Mikkeli $\quad \ldots \ldots \ldots \ldots \ldots \ldots .1 .188$

Muut kaup. .......... 1.172

II kuntatyyppi ......... 1.767

III $\quad, \quad \ldots \ldots \ldots .1 .771$

Kuopion $l$.

Kuopio $\quad \ldots \ldots \ldots \ldots \ldots \ldots, 1.223$

Muut kaup. ........ 1.418

Varkaus ............ 1.473

I kuntatyyppi $\ldots \ldots \ldots \quad 1.416$

II $\quad, \quad \ldots \ldots \ldots .1 .479$

III $\quad, \quad \ldots \ldots \ldots 2.009$

Vaasan $l$.

Vaasa $\ldots \ldots \ldots \ldots \ldots \ldots \quad 1.176$

Jyväskylä $\quad \ldots \ldots \ldots \ldots \ldots \quad 1.314$

Muut kaup. ja kaupp. .... 1.130

I kuntatyyppi $\ldots \ldots \ldots \quad 1.701$

II $\quad \ldots \quad \ldots \ldots \ldots 1.531$

III , , $\ldots \ldots \ldots 1.804$

Oulun $l$.

Oulu $\ldots \ldots \ldots \ldots \ldots \ldots \ldots \quad 1.551$

Muut kaup. .......... 1.581

I kuntatyyppi $\ldots \ldots \ldots .1 .772$

II $\quad, \quad \ldots \ldots \ldots .1 .913$

III $\quad \ldots \ldots \ldots 2.005$

Lapin $l$.

Kemi $\quad \ldots \ldots \ldots \ldots \ldots \ldots .1 .440$

Tornio .............. 1.422

I kuntatyyppi $\ldots \ldots \ldots .1 .843$

II $\quad$. $\quad \ldots \ldots \ldots .2 .177$

III $\quad, \quad \ldots \ldots \ldots .2 .272$

Koko maa 1.398 
Liitetaulukko 3. Eri viisivuotisikäryhmiin kuuluvien aviovaimojen keskimäärin vuosittain elävänä synnyttämīen lasten luku 1000 vastaavaan ikäryhmään Kuuluvaa aviovaimoa kohden vv. 1950-51.

-Lääni ja

/ tutkimusalue
Äidin ikä, v.

$$
\text { T5-19 } 20-24 \quad 25-29 \quad 30-34 \quad 35-39 \quad 40-44 \quad 45-49 \quad 15-49
$$

\section{Uudenmaan $l$.}

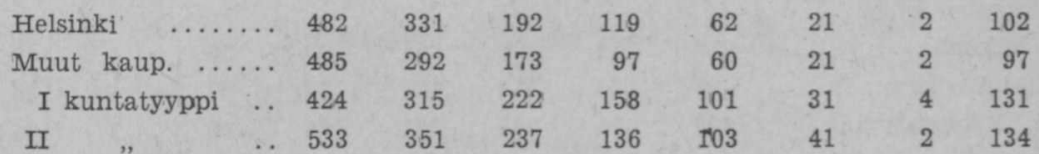

Turun ja Porin $l$.

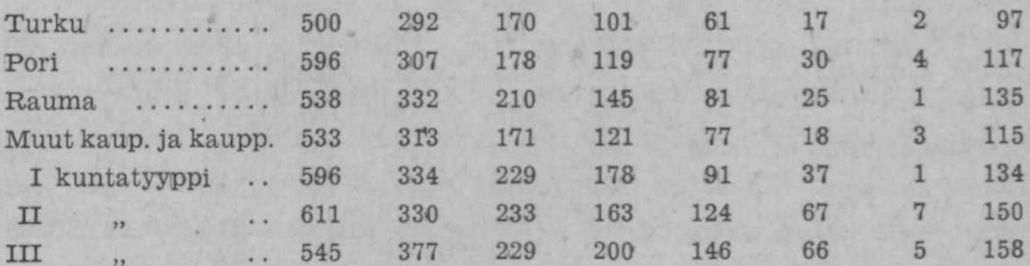

\section{Ahvenanmaa}

$\begin{array}{rrrrrrrrrr}\text { Maarianhamina } & \ldots 1250 & 306 & \text { I90 } & 99 & 43 & 21 & - & 105 \\ \text { II kuntatyyppi } & \ldots & 357 & 380 & 151 & 116 & 93 & 24 & 9 & 103\end{array}$

\section{Hämeen $l$.}

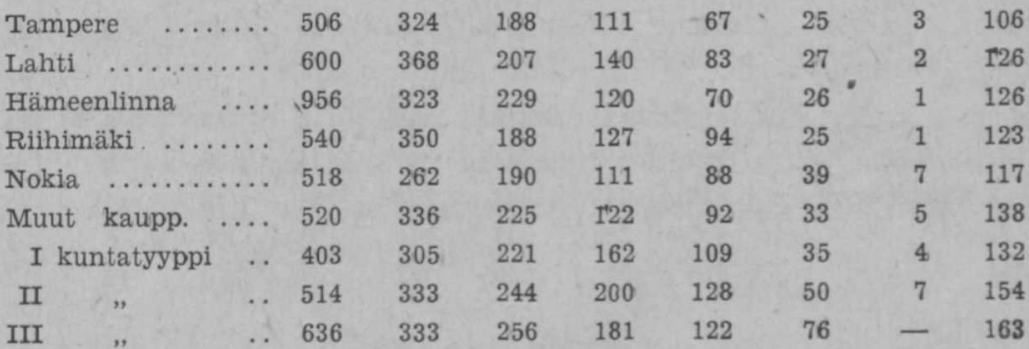


Kymen $l$.

$\begin{array}{rrrrrrrrrr}\text { Kotka } \ldots \ldots \ldots \ldots \ldots & 500 & 304 & 209 & 128 & 62 & 16 & 3 & 102 \\ \text { Lappeenranta } & \ldots \ldots & 658 & 351 & 213 & 144 & 77 & 26 & 5 & 124 \\ \text { Imatra } \ldots \ldots \ldots & \ldots & 500 & 291 & 229 & 129 & 84 & 36 & 1 & 119 \\ \text { Muut kaup. ja kaupp. } & 482 & 387 & 236 & 120 & 72 & 30 & - & 130 \\ \text { I kuntatyyppi } & \ldots & 450 & 311 & 260 & 155 & 125 & 10 & 4 & 141 \\ \text { II } \quad " & \ldots & 58 \mathrm{~F} & 368 & 267 & 170 & 117 & 55 & 7 & 153 \\ \text { III } & \ldots & 444 & 319 & 277 & 179 & 142 & 72 & 8 & 160\end{array}$

Mikkelin $l$.

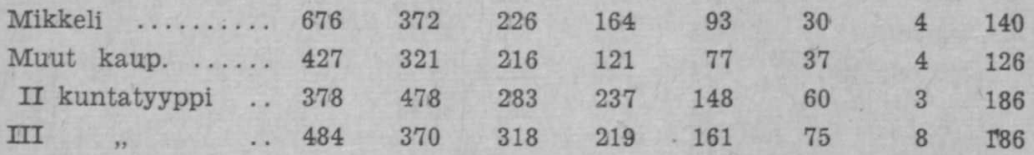

Kuopion $l$.

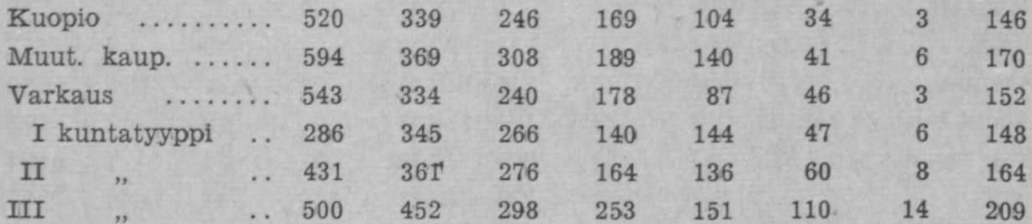

Vaasan $l$.

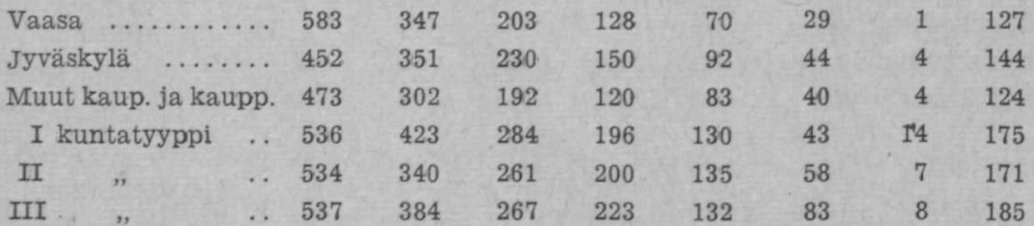

Oulun $l$.

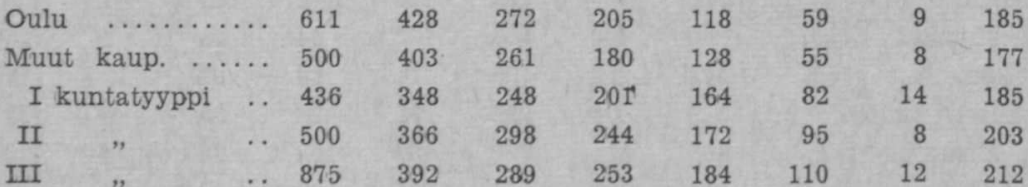

Lapin $l$.

\begin{tabular}{|c|c|c|c|c|c|c|c|c|}
\hline Kemi & & 500 & 379 & 244 & 141 & 94 & 29 & 3 \\
\hline Tornio & & 400 & 445 & 250 & 194 & 133 & 36 & 21 \\
\hline I kuntatyyppi & $\cdots$ & 413 & 342 & 263 & 234 & 147 & 70 & 14 \\
\hline , & & 516 & 412 & 337 & 254 & 205 & 109 & 14 \\
\hline , & & 521 & 437 & 327 & 299 & 225 & 140 & 17 \\
\hline Koko & maa & 499 & 349 & 240 & 172 & 116 & 53 & 6 \\
\hline
\end{tabular}

